\title{
THE PUBLIC ENFORCEMENT OF SANCTIONS AGAINST ILLEGAL PHOENIX ACTIVITY: SCOPE, RATIONALE AND REFORM
}

\author{
Michelle Welsh ${ }^{*}$ and Helen Anderson ${ }^{* *}$
}

\begin{abstract}
The loss suffered by unsecured creditors of all insolvent companies is the non-payment in full of amounts rightfully owed to them. This loss is all the more unacceptable to creditors when a company has been illegally phoenixed by the transfer from the insolvent company of assets at undervalue. One way of increasing the pool of funds available for distribution to creditors is to issue proceedings seeking compensation against directors alleging that their 'phoenixing' amounted to a breach of directors' duties or insolvent trading. Such an action may be instigated by the liquidator and by ASIC. ASIC's enforcement role can be contrasted with the recovery role of the liquidator where the latter acts primarily in the furtherance of private interests, being those of the insolvent company's creditors; ASIC's mandate, on the other hand, is to act in the public interest. The purpose of this article is to examine the enforcement roles of liquidators and ASIC where suspected illegal phoenix activity has occurred. Following consideration of the difficulties faced by liquidators acting on behalf of creditors of phoenixed companies, this article considers whether it is appropriate, from a policy perspective, for the public regulator to promote private interests by exercising its enforcement powers for the benefit of creditors. The argument in favour of a publicly funded regulator seeking compensation for creditor losses is particularly compelling in the context of illegal phoenix activity, given the inability of creditors to bring enforcement proceedings themselves and the difficulties faced by liquidators when they seek redress for creditors' losses.
\end{abstract}

\section{INTRODUCTION}

There are many practical impediments faced by plaintiffs when they seek redress for civil wrongs. These impediments, which are often discussed in the context of the access to justice debate, include issues of the cost and complexity of litigation, the structure of

* $\quad$ Associate Professor, Monash Business School, Monash University.

** Professor, Melbourne Law School, University of Melbourne. The authors thank the Australian Research Council for its generous support for this research: DP140102277, 'Phoenix Activity: Regulating Fraudulent Use of the Corporate Form'. 
the legal system, and the scope for private settlement of disputes. ${ }^{1}$ This article is concerned with the impediments faced by a specific category of victim of civil wrongs - creditors of insolvent companies - and in particular creditors of insolvent companies that have been illegally 'phoenixed'. Illegal phoenix activity occurs when company controllers close down one company with unpaid debts and transfer its assets for undervalue to a newly created company, with the intention of exploiting the corporate form to the detriment of the creditors of the defunct company. The loss suffered by unsecured creditors of all insolvent companies is the non-payment in full of amounts rightfully owed to them. This non-payment is all the more unacceptable to creditors when a company has been illegally phoenixed. This is because the transfer from the insolvent company of assets at undervalue deliberately diminishes the funds that would otherwise have been available to the liquidator for sale and ultimate distribution to the creditors.

Insolvency law has a number of unusual features which impact on the ability of unpaid creditors to obtain redress for the loss they have suffered: the collective distribution regime that deprives individuals of their rights to bring separate actions; the fact that an insolvent company, by definition, lacks sufficient funds to pay all claimants; general ignorance about rights under complex corporate law; and underfunded liquidators, reluctant to initiate legal action, who are nonetheless acting on behalf of vulnerable creditors. Creditors of phoenixed companies are further impacted by the blurring of lines between legal and illegal behaviour that complicates the situation for whoever brings the action; the absence of a specific 'phoenix' offence; the apparently unassailable nature of the separate legal status of companies and the limited liability of its shareholders; and economic dogma that celebrates business triumph after business failure.

One way of increasing the pool of funds available for distribution to creditors of companies that have been illegally phoenixed is through an action seeking compensation for wrongdoing against directors. Directors of companies that have been illegally phoenixed may have committed a breach of duty or may have engaged in insolvent trading. ${ }^{2}$ As creditors of insolvent companies do not have enforcement rights, they are dependent on others, primarily liquidators, to take action on their behalf against these errant directors. The role of the liquidators is to advance the interests of creditors by finalising the affairs of companies being wound up; to recover company assets; to issue proceedings against directors seeking compensation where appropriate; and to distribute assets amongst eligible creditors. ${ }^{3}$ Yet liquidators face many impediments which limit their ability to effectively perform their role for the benefit of creditors. The

1 A 2014 Productivity Commission report contained recommendations to improve access to justice generally which included measures concerning consumers' lack of information about avenues of redress, the value of early and informal solutions, problems with the formal system of justice, and access to justice for disadvantaged people. Productivity Commission, Parliament of Australia, Inquiry Report No 72: Access to Justice Arrangements (2014), 41-72 $<$ http://www.pc.gov.au/inquiries/completed/access-justice/report/access-justicevolume1.pdf $>$.

2 Corporations Act 2001 (Cth) ss 180-183, 588G. Phoenixing may also constitute a range of tax crimes under the Taxation Administration Act 1953 (Cth) pt III div 2. Directors may also be liable for certain unremitted company tax obligations under Taxation Administration Act 1953 (Cth) sch 1 div 269. These are discussed further below.

3 Corporations Act 2001 (Cth) s 477. 
most significant is a lack of money which is particularly pronounced where phoenix activity has taken place.

Where suspected illegal behaviour may have occurred in the lead up to the insolvency, the public regulator, the Australian Securities and Investments Commission (ASIC), has enforcement powers against the directors personally. In exercising these powers, ASIC seeks specific deterrence to secure the future compliance of this director, as well as general deterrence to warn the regulated population. ASIC's enforcement role can be contrasted with the recovery role of the liquidator. While the latter acts primarily in the furtherance of private interests, being those of the insolvent company's creditors, ASIC's mandate is to act in the public interest. ASIC's governing legislation requires it to exercise its enforcement function in the 'interests of commercial certainty, reducing business costs, and the efficiency and development of the economy' ${ }^{4}$ Nonetheless, this dichotomy is not so clear-cut. The article will show that liquidators play an important quasi-regulatory role, assisting ASIC in detecting wrongdoing at the time of the external administration of a failed company. Likewise, ASIC's role in seeking to deter misconduct ${ }^{5}$ can facilitate creditor recovery where it seeks a compensation order against directors engaged in wrongdoing. In other words, seeking this private benefit for some creditors can be recognised as achieving a public benefit as well. By viewing the compensation order as the imposition of a penalty, general deterrence of wrongdoing can be achieved, and all creditors and market participants benefit through better compliance with the law.

The purpose of this article is to examine the enforcement roles of liquidators and ASIC where suspected illegal phoenix activity has occurred. Following consideration of the difficulties faced by liquidators acting on behalf of creditors of phoenixed companies, this article considers whether it is appropriate, from a policy perspective, for the public regulator to benefit private creditor interests. The fact that ASIC has been granted the power to seek compensation orders raises interesting normative questions about the appropriate approach of a public regulator in this context. Should a public regulator use the limited resources at its disposal to seek compensation on behalf of creditors who have suffered a loss as a result of illegal phoenixing? If so, should ASIC do this rather than seeking a penalty payable to the government? ${ }^{6}$ Even if $A S I C^{\prime}$ s sole objective is to deter phoenix activity - a purely public benefit purpose - obtaining a private benefit for victims might be an appropriate use of resources if it is done in furtherance of that purpose and does not detract from it. This could be achieved via a civil penalty application alleging a contravention of the duties owed by directors. A compensation remedy is available for this ${ }^{7}$ in addition to disqualification and pecuniary penalties. The argument in favour of a publicly funded regulator seeking compensation

4 The ASIC Act 2001 (Cth) states that: In performing its functions and exercising its powers, ASIC must strive to: maintain, facilitate and improve the performance of the financial system and the entities within that system in the interests of commercial certainty, reducing business costs, and the efficiency and development of the economy: ASIC Act 2001 (Cth) s 1(2)(a).

5 See ASIC, Information Sheet 151: ASIC's approach to enforcement, September 2013 , <http://download.asic.gov.au/media/1339118/INFO_151_ASIC_approach_to_enforceme nt_20130916.pdf>, 1: 'We use enforcement to deter misconduct.'

6 See Michelle Welsh, 'Realising the Public Potential of Corporate Law: Twenty Years of Civil Penalty Enforcement in Australia' (2014) 42(1) Federal Law Review 217 for a discussion of this issue in the context of ASIC's enforcement of the directors' duties generally.

7 Corporations Act 2001 (Cth) s $1317 \mathrm{H}$ 
for creditor losses is particularly compelling in the context of illegal phoenix activity, given the inability of creditors to bring enforcement proceedings themselves and the difficulties faced by liquidators when they seek redress for creditors' losses. However, the article also notes recent concerns about ASIC's enforcement record in any context. ${ }^{8}$

This article is divided into five parts. Part II examines the difficulties faced by creditors of insolvent companies that have been phoenixed and explains the liquidation process that imposes a collective recovery regime. Part III examines the role of liquidators and the factors that restrict their ability to obtain redress for the losses suffered by unsecured creditors. Part IV examines the role of ASIC and considers, in light of the difficulties faced by liquidators in successfully running recovery proceedings, whether seeking compensation from directors of phoenixed companies in order to facilitate recovery for unsecured creditors is an appropriate use of its resources. Part $\mathrm{V}$ concludes.

\section{CREDITORS' AVENUES FOR REDRESS FOR UNPAID DEBTS IN INSOLVENCY}

The basic tenet of company law is that the company is a separate legal entity, so the debts that it incurs - whether tax debts, accrued employee entitlements or unpaid suppliers - are the debts of the company and not of its directors, managers or shareholders. Shareholders enjoy limited liability, meaning that they are not liable to contribute further funds to the company once their shares are fully paid. ${ }^{9}$ Creditor self-protection plays a major part in the traditional theoretical justification for shareholder limited liability. Ex ante, creditors are expected to seek security, either from the debtor company or its controllers, or else charge more for goods and services to compensate for the occasional loss. ${ }^{10}$ However, these arguments do not hold for all creditors. For example, small trade creditors are unlikely to have the bargaining power to obtain security or charge a premium, and the preferential status of secured creditors such as banks exacerbates the financially tenuous position of these unsecured creditors.

Where companies are solvent, creditors may initiate private enforcement actions against them for unpaid debts. However, once the company is insolvent, debt recovery must take place through the process of liquidation. ${ }^{11}$ Once a company has entered liquidation, the rights of individual creditors to recover from the debtor company are stayed $^{12}$ and their claims, and the claims of other unsecured non-prioritised creditors, ${ }^{13}$

8 See generally Senate Economic References Committee, Commonwealth Senate, Performance of the Australian Securities and Investments Commission (June 2014) [17.1] and ch 17 generally ('SERC, Performance of ASIC').

9 Corporations Act 2001 (Cth) s 516

10 Paul Halpern, Michael Trebilcock and Stuart Turnbull, 'An Economic Analysis of Limited Liability in Corporation Law' (1980) 30 University of Toronto Law Journal 117; Frank Easterbrook and Daniel Fischel, The Economic Structure of Corporate Law (Harvard University Press, 1991) ch 2; Richard Posner, Economic Analysis of Law (Aspen Publishers, $5^{\text {th }}$ ed, 1998); Richard Posner, 'The Rights of Creditors of Affiliated Corporations' (1976) 43 University of Chicago Law Review 499.

11 Because this article is concerned with ASIC's role in augmenting enforcement actions by liquidators, it does not consider voluntary administration, one of the alternatives to liquidation.

12 Corporations Act 2001 (Cth) s 471B.

13 Ibid ss 555, 556. 
are paid by the liquidator from a pool of funds once the assets of the company are collected and realised. ${ }^{14}$

Liquidation as a collective recovery regime theoretically makes good sense. It removes the wasteful and potentially inefficient realisation of the company's assets by individual creditors. This leads to administrative efficiencies at the time of liquidation. The collective scheme is intended to result in an increased aggregate pool of assets. ${ }^{15} \mathrm{In}$ other words, the total amount received by creditors as a group is as much or more than the sum of what they would have received if they had enforced the claims individually. ${ }^{16}$ In exchange for receiving these benefits, creditors 'agree' to stay their rights to take individual action. Many creditors are assumed to be risk averse, and to prefer to receive a more certain, lesser sum than a less certain, greater one. ${ }^{17}$ It takes away the benefits of being the first creditor to claim, 18 and therefore avoids costly and duplicative monitoring of the company's solvency. ${ }^{19}$

Nonetheless, by definition, the pool of funds available for distribution will not be sufficient to meet all creditors' claims. ${ }^{20}$ The difficulties faced by unsecured creditors in securing payment of their debts may be exacerbated where illegal phoenix activity has occurred. A phoenix company is one that arises from the ashes of its failed former self. There are a variety of definitions used by regulators and other stakeholders ${ }^{21}$ but none

14 Ibid s 477.

15 Thomas Jackson, 'Bankruptcy, Non-Bankruptcy Entitlements, and the Creditors' Bargain' (1982) 91(5) Yale Law Journal 857, 864.

16 See Flessner, describing the capitalist 'common pool' philosophy. He observed that under this philosophy, claimants in the aggregate must realise as much as they would have received if they had enforced the claims themselves. Alex Flessner, 'Philosophies of Business Bankruptcy Law: An International Overview' in Jacob Ziegel, Current Developments in International and Comparative Corporate Insolvency Law (Clarendon Press, 1994) 19, 23.

17 Jackson, above n 15, 862-63.

18 Jackson calls this 'the race to the courthouse': Jackson, above n 15, 862.

19 If creditors knew their own ability to recover was based upon being the first to initiate action, they would each spend time and money monitoring the company's solvency. The costs of monitoring would be passed on to the company, making goods and services more expensive. This would affect the profitability of the enterprise or else the company would in turn pass these costs on to their own customers.

20 Corporations Act 2001 (Cth) s 95A states that an insolvent company is one that is not solvent. Solvent is defined as being 'able to pay all the person's debts, as and when they become due and payable.'

21 See eg Commonwealth Treasury, 'Action against Fraudulent Phoenix Activity' (Proposals Paper, Treasury, Australian Government, 2009) 2; Law Reform Committee, “Curbing the Phoenix Company: First Report on the Law Relating to Directors and Managers of Insolvent Corporations' (Report No 83, Parliamentary Library, Parliament of Victoria, 1994); Australian Securities Commission, 'Project One: Phoenix Activity and Insolvent Trading Public Version' (Research Paper 95/01, May 1996) 39; Parliamentary Joint Committee on Corporations and Financial Services, Parliament of Australia, Corporate Insolvency Laws: A Stocktake (2004); Commonwealth, Royal Commission into the Building and Construction Industry, Final Report (2003) vol 8, 111-219; Australian Securities and Investments Commission, Small Business - Illegal Phoenix Activity (10 October 2014) <http://www.asic.gov.au/forbusiness/your-business/small-business/compliance-for-small-business/small-businessillegal-phoenix-activity/>. 
that is universally accepted. ${ }^{22}$ While the term 'phoenix company' can be used to describe the perfectly legal, even desirable, rescue of a viable business through a new corporate entity, generally it is used in a pejorative sense to capture some aspect of impropriety on the part of the defunct company's controllers. Illegal phoenix activity involves company controllers closing down one company with the deliberate intention of leaving its debts unpaid within that insolvent entity, and then transferring 'the business' - assets, goodwill, premises, possibly a similar name - to a newly created company. A common feature is that the assets are transferred for little or no consideration, leaving the failed company without the means to meet its obligations. The illegality stems from this improper intention to exploit the corporate form - the separate legal entity of the company and the limited liability of its shareholders - to the detriment of unsecured creditors. This behaviour breaches directors' duties ${ }^{23}$ and can also attract criminal sanction. ${ }^{24}$

The avenues for recovery of amounts unpaid by phoenixed companies largely depend upon who the victim is. This is the case in all liquidations, whether or not phoenix activity is involved. Those who suffer most from illegal phoenix activity are the ATO and its state revenue office counterparts. The ATO is responsible for gathering taxes such as income tax, including Pay-As-You-Go deductions withheld from employees' pay packets (PAYG(W)), as well as the superannuation guarantee charge (SGC) which is levied on employers who fail to make super contributions to employees' nominated funds. The state revenue offices gather taxes such as land tax and payroll tax. Each of these taxes is susceptible to non-payment through illegal phoenix activity because the primary liability falls on the failed company and not on its controllers or shareholders.

Employees are significant victims of illegal phoenix activity because their unpaid wages, leave entitlements, payments in lieu of notice and redundancy entitlements are often sizable debts of the failed company. Where a company is deliberately liquidated to shed debts, the employees are likely to lose not only their entitlements but also their employment. While the newly created company may take on some or even all of the defunct company's employees, those employees have no legal rights to demand that it does so. Employees enjoy the status of priority creditors and are also the beneficiaries of a taxpayer-funded scheme, discussed below. In some instances, dismissing employees and forcing them to seek government advances to cover their entitlements may be the reason that motivates the company's closure.

Trade creditors are frequently the victims of illegal phoenix activity. These include suppliers of goods or services to the failed company. Unlike lenders owed large amounts who seek security over the company's assets or a personal guarantee from company controllers, trade creditors may not seek any security from the company either because their debts are relatively small or because they lack the bargaining power to insist upon it. Therefore they are likely to recover little or nothing after the liquidation process has been completed. However, not all trade creditors are necessarily treated the same. Some

22 See generally, Helen Anderson et al, Defining and Profiling Phoenix Activity, Centre for Corporate Law and Securities Regulation, December 2014 <http://law.unimelb.edu.au/_data/assets/pdf_file/0007/1709503/15-

Definingandprofilingphoenixactivity-reportfinal2.pdf $>$.

23 Corporations Act 2001 (Cth) ss 180-183.

24 Ibid s 184. 
may be treated more favourably, especially if the newly formed company needs to continue purchasing from that supplier. This commonly occurs through secret arrangements where the new company or its controllers pay the amount owed by the defunct company. This is unjust to those creditors who will receive nothing. Customers of the failed company who have prepaid for goods or services fall into this same category.

Competitors of the phoenix company are the final group of victims of illegal phoenix activity. Some companies tender for work based on their intention to liquidate, leaving the unpaid debts of taxes, wages and suppliers quarantined within the failed entity. They then commence business again through a new company and repeat the process. Law-abiding competitors are undercut by this cheaper tendering and may genuinely be driven out of business. This may lead to them also engaging in illegal phoenix activity through their next company. Haines notes the significance of economic pressures on business and comments that '[i]f the profit levels are so tight that ... compliance is not compatible with staying in business, then ... non-compliance is the likely result. ${ }^{25}$

Because of the damage done by phoenix activity to all of these groups, deterrence of deliberate behaviour to shed debts is a vital public benefit, and public interest considerations have led to both revenue authorities and employees having special means of recovery. Where the victim is a revenue authority such as the ATO or a state revenue office, the roles of victim and regulator with powers to seek recovery are combined. Revenue authorities can, like other unsecured creditors, prove their debts in the liquidation of the company and receive a pro rata payment of the amount owed. In addition, the ATO in particular has a suite of tools that it can use to recover from the directors of the company personally. ${ }^{26}$ For example, directors who fail to cause their company to remit PAYG(W) taxes or pay superannuation can be subject to personal liability for these amounts if they do not promptly place the company into liquidation or voluntary administration. ${ }^{27}$ This is available to the ATO whether or not the directors had an improper intention in failing to remit the amounts on behalf of the company. The ATO may also seek a security bond where there is a suspicion that tax may not be remitted in future. ${ }^{28}$

As noted above, employees are priority creditors in the liquidation ${ }^{29}$ and are also the beneficiaries of a reasonably generous taxpayer-funded scheme. ${ }^{30}$ In addition, employees have a degree of support from 'champions' such as their trade union and the Fair Work Ombudsman (FWO). However, this does not necessarily mean that employees are fully compensated for what they are owed. The statutory priority under s 556(1)(e)-(h) is useful where an employer company has some assets remaining after paying the costs of the liquidation but is cold comfort where the assets of that company have been removed from the company as a result of illegal phoenix activity. The

25 Fiona Haines, The Paradox of Regulation What Regulation Can Achieve and What It Cannot (Edward Elgar, 2011) 22.

26 See further Anderson et al, Defining and Profiling Phoenix Activity, above n 22.

27 Taxation Administration Act 1953 (Cth) sch 1 s 269-15.

28 Ibid s 255-100.

29 Corporations Act 2001 (Cth) s 556.

30 The General Employee Entitlements and Redundancy Scheme (‘GEERS’) was the taxpayerfunded safety net scheme for unpaid wages and other entitlements for employees of insolvent employers. This was replaced by the Fair Entitlements Guarantee in 2012. 
taxpayer funded scheme, currently in the form of the Fair Entitlements Guarantee (FEG), partly makes up for that deficiency but is subject to limits. ${ }^{31}$ The FWO may commence action against the errant employer for failure to pay wages as a breach of the Fair Work Act ${ }^{32}$ as well as against the company's controllers for their involvement in this breach. ${ }^{33}$ However, such action is subject to the FWO's own resource constraints regarding litigation, ${ }^{34}$ and is not a means by which the employee victims of illegal phoenix activity can recover the amounts owing to them. ${ }^{35}$ Unions have the right to bring actions for enforcement of some provisions of the Fair Work Act ${ }^{36}$ but are themselves subject to resource constraints. ${ }^{37}$

Other unsecured creditors such as trade creditors and customers who have made prepayments, are, by comparison, friendless. As discussed, they lack the ability to sue once the company has entered liquidation. ${ }^{38}$ More than most other creditors, the ability of unsecured trade creditors to recover amounts owing to them is in the hands of the liquidator, and to some extent, ASIC. For this reason, they are the focus of this paper. The next Part examines the role of the liquidator in promoting the interests of the unsecured creditors and in playing a quasi-regulatory role on behalf of ASIC.

\section{THE ENFORCEMENT ROLE OF LIQUIDATORS}

The liquidation process itself is usually initiated by a creditor issuing the debtor company with a statutory demand to pay a specified amount. If it remains unsatisfied at the end of 21 days and the company has not applied to have it set aside, ${ }^{39}$ a creditor can then apply to have the company wound up in insolvency ${ }^{40}$ which the court may order. ${ }^{41} \mathrm{~A}$ liquidator is appointed and is given a wide variety of powers ${ }^{42}$ to gather

31 Australian Government Department of Employment, Fair Entitlements Guarantee (8 June 2016), <https://employment.gov.au/fair-entitlements-guarantee-feg>.

32 Fair Work Act 2009 (Cth) ss 45, 50.

33 Ibid s 550.

34 The FWO only commences litigation where there is sufficient evidence and, on balance, it considers that is in the public interest to do so and a proper response to the conduct. See FWO, Guidance Note 1 - Litigation Policy <http://www.fairwork.gov.au/about-us/policiesand-guides/internal-policies-and-plans\#guidenote>.

35 It is also possible for the penalty ordered to be payable to the employees; see Fair Work Act 2009 (Cth) s 545(3). The court may order compensation against those in breach of civil remedy provisions of the Fair Work Act pursuant to s 545(2)(b) but there are questions over the availability of the compensation remedy against accessories. See further Helen Anderson and John Howe, 'Making Sense of the Compensation Remedy in Cases of Accessorial Liability under the Fair Work Act', (2012) 36(2) Melbourne University Law Review 335.

36 Fair Work Act 2009 (Cth) s 539.

37 For a fuller discussion of the recovery rights of employees, see Helen Anderson, The Protection of Employee Entitlements in Insolvency: An Australian Perspective (Melbourne University Publishing, 2014) and her articles cited therein.

38 Corporations Act 2001 (Cth) s 471B. Note, however, the ability to seek leave from the court to commence proceedings despite the liquidation. This might occur where the remedy sought is not financial but rather an injunction against the failed company. See, for example, Commissioner for Consumer Protection v Unleash Solar (in liq) Pty Ltd [2015] FCA 348.

39 Corporations Act 2001 (Cth) ss 459C, 459G.

40 Ibid s 459P.

41 Ibid s 459A.

42 Ibid s 477 
together the company's assets for the purpose of distributing them in accordance with the priorities specified in the Act. ${ }^{43}$

One way of improving the position of unsecured creditors is to increase the pool of funds that is available to the liquidator. This could be done through a successful action against the directors of the company alleging that they have breached their duty. As stated above, illegal phoenix activity may constitute a breach of a director's duty to act for a proper purpose, and not to misuse their position to make a gain for themselves or someone else or cause detriment to the company. ${ }^{44}$ If the transfer of assets from the failed company for undervalue constitutes an uncommercial transaction, directors may also breach the duty to prevent insolvent trading. ${ }^{45}$ While creditors have some direct recovery rights against directors with respect to insolvent trading, these may only be exercised with the liquidator's consent or leave of the court. ${ }^{46}$ This requirement, and the stay on legal action by unsecured creditors that comes into being on the making of the winding up order, means that creditor recovery is largely in the hands of a third party, the liquidator.

Where the liquidator issues an enforcement action against directors alleging a breach of duty or insolvent trading, the remedy sought is compensation. It is essentially a private enforcement action because the liquidator acts on behalf of an individual company against its directors for the purpose of correcting a wrong done to that company. Compensation is traditionally seen as a private remedy designed to deliver corrective justice for harm that has been done to victims personally. ${ }^{47}$ The victims of a phoenix company are its creditors and the harm is the reduction in funds that was caused by the phoenix activity of the directors. Any compensation ordered against the directors is paid to the company for the ultimate benefit of those unsecured creditors.

However, the ability of the liquidator to obtain this compensation, and indeed to perform all of the tasks within their remit, is impacted by the amount of assets held by the company at the time of its liquidation. It determines the scope of the investigation that they are able to undertake and the likelihood of recovery actions being issued against directors. The very act of stripping assets from the failing company through illegal phoenix activity not only deprives its creditors of their recovery but also limits the ability of the liquidator to perform their role. By the time an illegally phoenixed company is referred to a liquidator for the purpose of formally ending its existence, there may be few or no assets left to fund investigations or recovery actions against the directors, and liquidators have no incentive to accept the engagement.

In some cases the stripping of the assets may lead to the company not being placed into liquidation at all. If no creditor comes forward to finance the liquidation and there

$43 \quad$ Ibid s 556.

44 Ibid s 181, s 182. See for example, the well-known breach of duty cases, Grove v Flavel (1986) 43 SASR 410 and McNamara v Flavel (1988) 6 ACLC 802.

45 Corporations Act 2001 (Cth) s 588G(1A).

46 Ibid ss 588R, 588T. Company creditors also have some potential to seek redress against solvent companies pursuant to s 1324, particularly in relation to share capital transactions under Chapter 2J of the Corporations Act 2001 (Cth).

47 Australian Law Reform Commission, Securing Compliance: Civil and Administrative Penalties in Australian Federal Regulation Discussion Paper 65 (2002) [2.15]. See also Kenneth Mann, 'Punitive Civil Sanctions; The Middleground Between Criminal and Civil Law' (1992) 101(5) Yale Law Journal 1795, 1799. 
are insufficient funds within the company to cover the liquidator's fees and expenses, the insolvent company is likely to remain dormant until ASIC decides to deregister it for failure to submit required returns and pay annual fees. ${ }^{48}$ ASIC's ability to wind up abandoned companies and seek their liquidation is noted below in Part IV, but at this point, it should be noted that the creditors of these companies can only rely on ASIC for enforcement action against any wrongdoers.

The Government's Assetless Administration Fund (AAF) was set up with the purpose of paying for assetless administrations. ${ }^{49}$ However it generally does not cover the liquidation costs of asset recoveries except in specified circumstances. ${ }^{50}$ Since 2012, these circumstances are suspected fraudulent or unlawful phoenix activity. ${ }^{51}$ However, in order to qualify for AAF funding, the liquidator must have obtained sufficient evidence to support the banning or enforcement action. ${ }^{52}$ The scheme therefore relies on a liquidator making substantial inquiries, paid for out of their own pocket or directly by the creditors, prior to being funded by the $\mathrm{AAF}$, and also being willing to prepare the detailed paperwork of the funding application. ${ }^{53}$

Exacerbating the difficulties for creditors is the advent of the turnaround specialist. These unregulated ${ }^{54}$ business advisory services are believed to advise companies in financial difficulties to engage in illegal phoenix activity as a means of saving their businesses from the burden of debt. ${ }^{55}$ Some registered liquidators have also been involved in improper behaviour, 56 but the majority perform their statutory

48 Corporations Act 2001 (Cth) ss 601AB(1A), 601AB(1), 1447. Companies deregistered annually outnumber companies in liquidation by approximately ten to one. For example, according to ASIC's annual reports, the total numbers of companies deregistered in 2012-13, 2013-14 and 2014-15 were 105 627, 109147 and 112714 respectively. In those same three years, the total numbers of companies entering some form of external administration (but not necessarily deregistered that same year) were 10746,9822 and 9177 respectively.

49 ASIC, Regulatory Guide 109: Assetless Administration Fund: Funding Criteria and Guidelines, RG109, November 2012.

50 Ibid RG109.5.

51 Ibid RG109.28. Data has been requested from ASIC about the extent to which AAF funding has been paid for asset recovery in phoenix circumstances, but at the date of writing, no response has been received.

52 Ibid

53 The details are contained in the appendices to ASIC, Regulatory Guide 109: Assetless Administration Fund: Funding criteria and guidelines, RG109, November 2012.

54 Turnaround specialist are not covered by the regulations that govern liquidators.

55 See Australian Securities and Investments Commission v Franklin (liquidator), in the matter of Walton Constructions Pty Ltd [2014] FCAFC 85 ('ASIC v Franklin'). ASIC v Franklin illustrates the operation of pre-insolvency advisors and the difficulties facing ASIC in tackling their behaviour directly. The case was a successful action brought by ASIC for the removal of a liquidator on the basis of apprehended bias. The liquidator was engaged by two failing companies through a referral by the pre-insolvency business advisory group of companies, and it appeared that the pre-insolvency advisors had engaged in phoenix activity (at [52]). The apprehension of bias arose because the group had previously made a number of referrals to the same liquidator, and ASIC alleged that the liquidator might not make the required 'vigorous' inquiries if this jeopardised future referrals of work.

56 See for example, the successful action brought by ASIC against Paul Scott and Graeme Dwyer, reported in the Sydney Morning Herald newspaper: Sally Rose, 'Gold Coast accountant Paul Anthony Scott latest scalp as ASIC bares teeth', The Sydney Morning Herald (Sydney) 20 February 2015. 
requirements and adhere to professional guidelines set by the Australian Restructuring Insolvency and Turnaround Association (ARITA). ${ }^{57}$ Nonetheless, the importance of sending a clear message of deterrence is highlighted where some advisors are complicit in wrongdoing. Obtaining compensation for those creditors adversely affected by that wrongdoing, and publicising it well, would achieve that public benefit as well as overcoming the damage caused.

In addition to fulfilling their traditional role, it should be recognised that liquidators also serve a public interest role. While the Corporations Act empowers liquidators to finalise the affairs of companies being wound up, recover company assets including through litigation, and distribute them amongst eligible creditors, ${ }^{58}$ it also requires liquidators to report a number of matters to ASIC. ${ }^{59}$ A central part of this reporting relates to misconduct before and during external administrations by corporate controllers. Liquidators notify ASIC whether they suspect the conduct breaches civil penalty or criminal laws, including those breaches that occur in the phoenix context, and whether they hold documentary evidence to support their claims.

This is vital intelligence that ASIC uses to select cases to pursue further. It is no exaggeration to say that no-one is as close to the affairs of a failed company as its liquidator and therefore no-one else can determine whether it is a legal or illegal phoenix with the same degree of experience and knowledge of the law. ASIC's 2014-15 Annual Report noted that 'ASIC allocates its resources to achieve the greatest market impact. With less resources, we are generally unable to conduct random sampling-based surveillance. Instead, we focus on strategically important gatekeepers to direct surveillance resources towards the risks that pose the greatest threat.' 00 ASIC rightly points out that '[e]xternal administrators are the front-line investigators of insolvent corporations.' 61 Their work contributes towards '(a) maintaining the integrity of the marketplace; and (b) promoting investor and consumer confidence.' ${ }^{62}$ The investigation and detection roles of liquidators have also been judicially acknowledged. ${ }^{63}$

The directors' duties that may be enforced by the liquidator in the context of illegal phoenix activity are civil penalty provisions. This means that ASIC is also able to play an enforcement role, and this is examined in the next Part. Given the difficulties faced by liquidators in recovering on behalf of creditors, particularly in phoenix situations, and the work done by liquidators to assist ASIC in phoenix detection, we now turn to consider what ASIC may do to assist them.

57 See Australian Restructuring Insolvency and Turnaround Association, Code of Professional Practice, 3rd edition, <http://www.arita.com.au/about-us/arita-publications/code-ofprofessional-practice>.

58 Corporations Act 2001 (Cth) s 477.

59 This reporting is done in compliance with ASIC, Regulatory Guide 16: External administrators - Reporting and Lodging, RG16, July 2008. Available at <http://asic.gov.au/for-financeprofessionals/registered-liquidators/applying-for-and-managing-your-liquidatorregistration/rg-16-external-administrators-reporting-and-lodging/ $>$.

60 ASIC, Annual Report 2014-2015 (15 October 2015) 36.

61 ASIC, above n 59, RG16.4.

62 Ibid RG16.5.

63 Australian Securities and Investments Commission v Midland Hwy Pty Ltd (administrators appointed); in the matter of Midland Hwy Pty Ltd (administrators appointed) [2015] FCA 1360, [78][79]. 


\section{THE ROLE OF THE PUBLIC REGULATOR}

There are a number of enforcement mechanisms at ASIC's disposal if it suspects that a company's controllers have engaged in illegal phoenix activity. ${ }^{64}$ As noted above, one of those mechanisms is a civil penalty application issued against the directors personally, seeking compensation for an alleged breach of duty. ASIC may also seek director disqualification and/or pecuniary penalties, 65 other types of director disqualifications instigated either via a court application ${ }^{66}$ or an internal administrative procedure, ${ }^{67}$ and the winding up of dormant companies. ${ }^{68}$ This final mechanism acts as a small contribution to creditor compensation through the appointment of a liquidator, although its very limited scope ${ }^{69}$ and its few uses ${ }^{70}$ confirm that this process is of relatively little benefit to creditors generally. The only real benefit is to employees as it provides them with access to the Fair Entitlements Guarantee, allowing for the potential of obtaining compensation. However, it plays no 'public benefit' role by causing a wrongdoer to pay in some way for their action.

Public enforcement is not constrained by the same factors that constrain private enforcement such as a lack of assets to fund investigations and litigation. In addition, liquidators must take into account the likelihood of recovery, should the action against the director be successful. Regardless of the culpability of the director, a liquidator is unlikely to take action if they believe the director does not have sufficient personal assets to meet a judgment debt. ${ }^{71}$ This is not a factor that needs to constrain the public regulator.

64 For a full survey of laws that might be utilised in the phoenix context, see Anderson et al, Defining and Profiling Phoenix Activity, above n 22.

65 Corporations Act 2001 (Cth) ss 206C, 1317G.

66 Ibid ss 206D, 206E. ASIC may also apply to the court for a disqualification order pursuant to Corporations Act 2001 (Cth) s 206E where a person has twice been a director of a corporation that has contravened the Act or has twice contravened the Act while they were an officer of a body corporate.

67 Ibid s 206F. This provision allows ASIC itself to disqualify for up to five years a person who, within the past seven years, has been an officer of two or more corporations where adverse liquidator reports have been lodged with ASIC.

68 Ibid s 489EA. ASIC may wind up a dormant company under s 489EA of the Corporations Act where it becomes apparent that it is not carrying on business, evidenced for example by the non-return of ASIC forms or the non-payment of fees. ASIC may then appoint a liquidator to wind up the affairs of the company.

69 According to ASIC, Regulatory Guide 242: ASIC's power to wind up abandoned companies, RG242, January 2013, '[w] e will exercise this power to help employees of abandoned companies who are owed employee entitlements to access an advance under the Fair Entitlements Guarantee Act 2012 (Fair Entitlements Guarantee Act).', at 4. However, even in these circumstances, ASIC will not necessarily act: see RG242.12.

70 In 2014-15, there were 112714 companies deregistered (ASIC, Annual Report 2014-2015 (15 October 2015) 66) of which 37600 companies were abandoned companies which were deregistered by ASIC for failure to pay fees: Corporations Act 2001 (Cth) s 601AB. (Data supplied by email from Adrian Brown of ASIC to the author, 18 March 2016.) In the same period, ASIC applied for the winding up of 31 abandoned companies: ASIC, Report 444 ASIC's Enforcement Outcomes January - July 15, 29; ASIC, Report 421 ASIC's Enforcement Outcomes July to December 2014, 51.

71 For a discussion of the advantages of public enforcement in the context of directors' duties generally see Renee Jones and Michelle Welsh, 'Toward a Public Enforcement Model for 
This Part now considers whether ASIC should use its limited resources to seek compensation that will ultimately benefit creditors of companies that have been phoenixed. First, we consider whether ASIC should do so to enhance compliance. Secondly, we consider whether compensation should be sought even if compliance were not enhanced. Finally, we consider the background to ASIC's compensation power and comment upon its subsequent use.

\section{A The Compliance Focused View of Public Regulation}

This section starts from the perspective that the objective of a public regulator is to secure future compliance. It argues that obtaining compensation for victims is an appropriate use of the regulator's resources, provided that it achieves that objective and does not detract from it. In the phoenix context, it can be done by bringing a civil penalty application alleging a contravention of the duties owed by directors and seeking a compensation order.

In order to explore the role of a public regulator in this context, it is useful first to consider the role of public regulation more generally. Black defines regulation as 'the sustained and focused attempt to alter the behaviour of others according to defined standards or purposes with the intention of producing a broadly identified outcome or outcomes' ${ }^{72}$ According to Baldwin, Cave and Lodge, the primary aim of regulation is to reduce behaviour that is harmful to others by either preventing an individual from engaging in it or by deterring others from doing so. ${ }^{73}$ The OECD defines regulation as that which 'serve[s] clearly identified policy goals', 74 and Haines says the role of regulation is to 'attempt to bring about a clearly defined end' ${ }^{75}$

The behaviour that requires modification in the phoenix context is the misuse of the corporate form to deliberately avoid the payment of debts, generally by the transfer of assets at an undervalue. Therefore, from a normative perspective, regulation of phoenix activity should deliver a sustained and focused attempt to alter the behaviour of persons who would otherwise engage in this type of activity. It should have the clearly defined policy goal, or clearly defined end, of reducing its future incidence and the future losses to unsecured creditors that would be caused by it. ${ }^{76}$

Directors' Duty of Oversight' (2012) 45 Vanderbilt Journal of Transnational Law 343 and in the context of the enforcement of securities law see Michelle Welsh and Vince Morabito, 'Public vs Private Enforcement of Securities Laws: An Australian Empirical Study’ (2014) 14 (1) Journal of Corporate Law Studies 39.

72 Julia Black, 'Critical Reflections on Regulation' (2002) 27 Australian Journal of Legal Philosophy $1,26$.

73 Robert Baldwin, Martin Cave and Martin Lodge, Understanding Regulation Theory, Strategy and Practice (Oxford University Press, 2nd ed, 2012) 247.

74 Organisation for Economic Cooperation and Development, OECD Guiding Principles for Regulatory Quality and Performance (2005) 3

<http://www.oecd.org/dataoecd/19/51/37318586.pdf>.

75 Haines, above $\mathrm{n} 25,8$.

76 See generally Welsh, above $\mathrm{n} 6$ for a discussion of the normative role of public regulation in the context of the enforcement of directors' duties. 
In 2006 Richard Macrory undertook a review of regulatory sanctions for the UK Government. The results of that review were published in Regulatory Justice: Making Sanctions Effective. ${ }^{77}$ According to the Macrory Report,

[r] gulatory sanctions are an essential feature of a regulatory enforcement toolkit and are central to achieving compliance by signalling the threat of a punishment for firms that have offended. Sanctions demonstrate that non-compliance will not be tolerated and that there will be a reprimand or consequence that will put the violator in a worse position than those entities that complied with their regulatory obligations on time. ${ }^{78}$

The potential for problems to arise when public regulators seek to promote private interests was recognized by the UK Department for Business, Innovation and Skills ('BIS') in its 2012 consultation paper entitled Private Actions in Competition Law: A Consultation on Options for Reform. ${ }^{79}$ Although focused on private enforcement in the competition context, the consultation paper includes a useful discussion of the role of a public regulator, the UK Office of Fair Trading ('OFT'), in facilitating redress. The BIS noted that 'alongside a strong private actions regime, the Government recognises that there are some situations where it may be appropriate for the public enforcement body to consider mechanisms for redress, as part of its administrative settlement of cases.' 80 However, the Department also acknowledged that a compensatory role should not detract from the regulators' role in detecting, investigating and sanctioning activity that contravenes the laws or regulations: ${ }^{81}$

Whilst recognising that any involvement in delivering redress would involve some resource implications, the Government would not wish the OFT to become so involved in the business of quantifying the degree of loss suffered by consumers or business that this led to an impairment in carrying out its other functions. To divert resources away from or delay enforcement activities in order to help facilitate compensation could cause a reduction in deterrence and therefore an increase in anticompetitive behaviour. ${ }^{82}$

The UK Government agreed with this approach, and in its response to the BIS report, stated that the

Government considers that the primary duty of the OFT will be to enforce the competition regime and undertake studies and investigations in the competition regime. Any work therefore that the OFT will undertake on redress schemes would be in addition to this primary competition work, and should not be a substantial burden on resource. ${ }^{83}$

77 Richard B Macrory, 'Regulatory Justice: Making Sanctions Effective' (2006) <http://webarchive.nationalarchives.gov.uk/20121212135622/http:/www.bis.gov.uk/files /file44593.pdf> ('Macrory Report').

78 Ibid 7.

79 United Kingdom Department for Business Innovation and Skills, Private Actions in Competition Law: A Consultation on Options for Reform (April 2012) 45 [6.26] <https://www.gov.uk/government/uploads/system/uploads/attachment_data/file/315 28/12-742-private-actions-in-competition-law-consultation.pdf $>$.

80 Ibid 45 [6.27].

81 Ibid 46 [6.29].

82 Ibid 46 [6.31].

83 United Kingdom Department for Business, Innovation and Skills, Private Actions in Competition Law: A Consultation on Options for Reform - Government Response (January 2013) 53 [6.35]

<https://www.gov.uk/government/uploads/system/uploads/attachment_data/file/701 85/13-501-private-actions-in-competition-law-a-consultation-on-options-for-reformgovernment-response1.pdf $>$. 
Deterrence theory relies on the economic premise that members of the regulated community will internalise the cost of non-compliance and if this cost can be set at a sufficiently high level, would-be non-compliers will comply with the law. ${ }^{84}$ This can be contrasted with private enforcement which serves private interests and is traditionally associated with notions of corrective justice. ${ }^{85}$

Scholars who support a compensatory role for public regulators point to synergies in the regulatory outcomes that can flow from both public and private enforcement. They allow regulators to promote both the interests of the victim of the regulatory contravention; by seeking an order designed to provide corrective justice, such as a compensation order; while at the same time furthering the public interest by seeking an order designed to provide distributive justice and deterrence, such as a fine or some sort of disqualification order. For example, Ezrachi and Ioannidou argue that a private enforcement action can also serve a deterrent function. They believe that private damages claims can provide a public interest outcome because they 'not only serve as a channel for corrective justice, but also supplement the deterrent function of public enforcement.' 86 Hodges argues that from an economic perspective,

the costs of non-compliance can equally well be produced by fines imposed by public authorities (whether enforcement authorities or courts) as by damages and costs imposed by private actions. Both mechanisms involve the same medium, money and pressure is therefore both equal and transferable between the two mechanisms. ${ }^{87}$

If both traditional public enforcement mechanisms, such as fines, and private damages claims can result in deterrence, then it should also be true that a compensation order imposed following a public enforcement action should produce a deterrent effect. From a deterrence perspective it should make little difference whether a public enforcement action results in a fine or a compensation order, assuming that the quantum of the orders is the same. Equally, there should be little difference from a regulator's point of view between an order that requires a defendant to pay an amount as compensation and an order that requires a defendant to pay an amount as a fine. ${ }^{88}$ As Hodges argues ' $[\mathrm{t}$ ] he concept that a public entity may deliver private remedies is merely the converse of the thesis that private bodies may deliver public enforcement. ${ }^{\prime} 9$

Writing in the context of the regulation of competition in the EU, Ezrachi and Ioannidou proposed the adoption by the member states of regimes that would provide

84 Christine Parker and Vibeke Lehmann Nielsen, 'What Do Australian Businesses Really Think of the ACCC, and Does It Matter?' (2007) 35(2) Federal Law Review 187, 192.

85 See above $\mathrm{n} 47$.

86 Ariel Ezrachi and Maria Ioannidou, ‘Public Compensation as a Complementary Mechanism to Damages Actions: From Policy Justifications to Formal Implementation' (2012) 3 Journal of European Competition Law \& Practice 536, 537.

87 Christopher Hodges, The Reform of Class and Representative Actions in European Legal Systems (Hart Publishing, 2008) vol 8, 196. Hodges states that '[1]aw and economics scholars have traditionally held that regulation and litigation are substitutes in the task of deterring potentially harmful conduct': at 200, citing Donald Wittman, 'Prior Regulation versus Post Liability: the Choice between Input and Output Monitoring' (1977) 6 Journal of Legal Studies 193.

88 Although arguably greater stigma may be attached to a compensation order that is the result of a public enforcement action than a private enforcement action.

89 Hodges above n 87, 228. 
what they termed 'public compensation.' 90 Under these regimes competition regulators could impose a compensation award in favour of the injured parties in addition to a fine, following an investigation. ${ }^{91}$ Ezrachi and Ioannidou argued that public compensation would advance

partial fusion of the compensatory function. Public compensation constitutes a hybrid approach to enforcement since it achieves a primarily private enforcement goal, that is compensation, through public enforcement mechanisms. At the same time though, it furthers deterrence as the primary goal of public enforcement. Thus, 'Public Compensation' transcends the dichotomy between public and private enforcement and the deterrence and compensation goals of competition law enforcement. 92

Therefore, in the phoenix context, the role of the publicly funded regulator should be to utilise the enforcement mechanisms at its disposal in strategic ways to reduce illegal behaviour by encouraging greater compliance with the relevant directors' duties. ${ }^{93}$ Responsive regulation theory has much to say about how the goals of compliancefocused regulation should be achieved. ${ }^{94}$ It requires regulators to choose from the available enforcement mechanisms the one that is most likely to encourage future compliance. The focus on future compliance requires public regulators to adopt a forward-looking approach, focused on changing future behaviour, rather than on achieving redress for victims of past contraventions. ${ }^{95}$

Nonetheless, depriving wrongdoers of the fruits of their illegal phoenix activity can send a valuable message of deterrence to those contemplating similar behaviour in the future. Parker notes the effectiveness of compensation as both restorative justice and effective deterrence, saying that ' $[\mathrm{t}]$ he ACCC experience ... shows ... that remedies or sanctions agreed through enforceable undertakings, such as victim compensation

90 Ezrachi and Ioannidou, above n 86, 537.

91 Ibid.

92 Ibid 538 (citations omitted)

93 See ASIC Act 2001 (Cth) s 1(2)(g) which provides that ASIC must strive to among other things 'take whatever action it can take, and is necessary, in order to enforce and give effect to the laws of the Commonwealth that confer functions and powers on it'.

94 Responsive regulation was developed and expanded by John Braithwaite and Ian Ayres. One of the tenets of responsive regulation is that the most successful regulators act strategically by selecting from their range of available enforcement mechanisms the one that is most likely to lead to future compliance. See, eg, Ian Ayres and John Braithwaite, Responsive Regulation: Transcending the Deregulation Debate (Oxford University Press, 1992); John Braithwaite, To Punish or Persuade: Enforcement of Coal Mine Safety (State University of New York Press, 1985) ('Punish or Persuade'). See also Brent Fisse and John Braithwaite, Corporations, Crime and Accountability (Cambridge University Press, 1993); Chris Dellit and Brent Fisse, 'Civil and Criminal Liability Under Australian Securities Regulation: The Possibility of Strategic Enforcement' in Gordon Walker, Brent Fisse and Ian Ramsay (eds), Securities Regulation in Australia and New Zealand (LBC Information Services, $1^{\text {st }}$ ed, 1994) 570; Fiona Haines, Corporate Regulation: Beyond 'Punish or Persuade' (Clarendon Press, 1997) 218. For a list of recent publications contributing to the responsive regulation debate: see John Braithwaite, 'The Essence of Responsive Regulation' (2011) 44 University of British Columbia Law Review 475, 479 n 9.

95 See above $\mathrm{n} 94$. 
arrangements, ... have often been tougher and more effective in addressing the problems of misconduct than court ordered fines.' 96

\section{B An Expansive View of the Role of Public Regulation}

Other commentators support a more expansive view of the role of a public regulator and argue that it should not be limited to simply securing compliance with the law and regulatory requirements. They argue that the role of a public regulator legitimately encompasses the seeking of compensation for victims of regulatory contraventions, regardless of whether this contributes to increased deterrence. For example, the Macrory Report describes the role of sanctions in the following terms:

Where regulatory non-compliance occurs, sanctions can ensure that businesses that have saved costs by non-compliance do not gain an unfair advantage over businesses that are fully compliant. Where breaches result in damage or other costs to society, sanctions can assist in ensuring that those in breach provide proper recompense. Sanctions can equally represent a societal condemnation of the regulatory breach, acting as a deterrent to the sanctioned business against future breaches, and sending a wider message to the regulated sector. ${ }^{97}$

In developing the principles underlying regulatory sanctions, Macrory considered the five purposes of sentences in criminal matters to which the Criminal Justice Act 2003 (UK) requires UK courts to have regard. Those purposes included the making of reparation by offenders to those persons affected by their offences' ${ }^{98}$ Macrory argued that six principles should be adhered to by those who design sanctioning regimes for non-compliance. Regulatory sanctions should:

1. Aim to change the behaviour of the offender;

2. Aim to eliminate any financial gain or benefit from non-compliance;

3. Be responsive and consider what is appropriate for the particular offender and regulatory issue, which can include punishment and the public stigma that should be associated with a criminal conviction;

4. Be proportionate to the nature of the offence and the harm caused;

5. Aim to restore the harm caused by regulatory non-compliance, where appropriate; and

6. Aim to deter future non-compliance. ${ }^{99}$

Principles one, three, four and six accord with the traditional view of the role of a public regulator. However, principles two and five envisage a wider role for the public regulator which could include seeking compensation for victims of the contravention, independent of any need to send a deterrent message. Macrory clearly had compensation in mind when he stated that principle five 'encompasses the needs of victims as well as ensuring that business offenders take responsibility for their actions and its consequences.' 100

96 Christine Parker, 'Restorative Justice in Business Regulation? The Australian Competition and Consumer Commission's Use of Enforceable Undertakings' (2004) 67(2) Modern Law Review 209, 236.

97 Macrory Report, above n 77, 15.

98 Ibid 27, citing Criminal Justice Act 2003 (UK) pt 12 s 142.

99 Ibid 10.

100 Ibid 31. 
The Macrory Report notes that the responses to the Review's interim report, while broadly supportive of the draft principles, generally called for some flexibility in their application. For example, the Macrory Report refers to the submission from the Financial Services Authority in which it says:

The Financial Services Authority (FSA) suggest that although the principle is a relevant consideration, not all cases can or should include a restorative element. For example, in some cases it may not always be possible to quantify the losses suffered by an identifiable person and in others individual losses as a result of regulatory breaches are more efficiently and effectively redressed through individuals directly pursuing claims with the firm concerned (through the Financial Ombudsman Services or through the Financial Services Compensation Scheme). The FSA suggest that Principle \#5 be qualified to make it clear that regulators need only consider whether a sanction should include a restorative element. ${ }^{101}$

\section{ASIC's Compensation Power in the Context of Phoenix Activity}

The civil penalty regime, which is at ASIC's disposal following duty breaches that occur in the phoenix context, allows for orders imposing a penalty, disqualification and compensation. Disqualification orders and pecuniary penalties both punish errant directors and act as a deterrent. The former also removes the director from the marketplace for the protection of future creditors. While the traditional role of compensation is to redress harm suffered by victims, the use of this order may also allow ASIC to achieve its objective of penalising wrongdoers, deterring future wrongdoing and securing increased compliance. The payment from the wrongdoer exerts the same punitive influence whether it is paid into consolidated revenue in the form of a pecuniary penalty, or to the victims of the wrongdoing in the form of compensation. Given the special difficulties faced by creditors in obtaining full payment of the monies owed to them in the phoenix context, there is a clear need for the public regulator to seek compensation from the directors personally when they have breached duties. If obtained, that compensation would be paid to the company and will increase the pool of funds that is available for distribution to creditors, particularly unsecured trade creditors who have no other champion. Arguably, this task fits both within the narrow compliance focused view as well the expansive view of the role of a public regulator.

However, this does not appear to be ASIC's approach. Its information statement on enforcement confirms that '[w]e can take enforcement action designed to punish wrongdoers, protect investors, preserve assets, correct disclosures or compensate people.' ${ }^{\prime 02}$ Yet these actions are not equally recognised in the text that follows. Nearly a page is dedicated to 'punitive action' 103 whereas a single paragraph deals with compensation. That paragraph clearly states ASIC's approach to seeking a compensation order:

We have powers under s 50 of the ASIC Act to begin a representative action to recover damages or property for persons who have suffered loss. We will ordinarily only take action to recover damages or property on a person's behalf if this would be in the public interest, beyond the interests of the affected consumers. We encourage investors to consider alternative options to recover damages or property from wrongdoers where

101 Ibid 28 (emphasis in original).

102 ASIC, Information Sheet 151: ASIC's approach to enforcement, above n 5, 4.

103 Ibid 5. 
possible, such as by lodging a dispute with the Financial Ombudsman Service or taking private legal action. 104

It is interesting that $\mathrm{ASIC}^{\prime}$ s statement does not even acknowledge its own powers to seek compensation for civil penalty breaches, nor the recovery of debt through a liquidator. The references to consumers, investors and the Financial Services Ombudsman seem to reflect a focus on market integrity and financial product complaints, rather than insolvency. It is also noteworthy that none of the other enforcement tools - punitive, protective, preservative or corrective action, negotiated resolutions or infringement notices - suggest that those with complaints seek redress elsewhere. It would therefore appear that ASIC's own view of its enforcement role is to achieve compliance or redress in some way other than seeking compensation for victims. It sends the message that ASIC does not want to be a source of private remedies for victims of corporate law breaches, even playing an ancillary role to that of the liquidator.

Yet drafters of the Corporate Law Reform Bill, which introduced civil penalty provisions into corporate law, were clearly of the view that seeking redress for victims was an appropriate role for a public regulator. ${ }^{105}$ The relevant provisions of the Bill came about as a consequence of the Cooney Report in 1989. ${ }^{106}$ It recommended that civil penalties be available for breaches by directors where no criminality is involved, and, in appropriate circumstances, people suffering loss as a result of a breach should be able to claim damages in the proceeding to recover the loss. ${ }^{107}$ The purpose of the civil penalty provisions was to sanction misconduct falling short of a criminal offence. 108 Other Australian regulators have been given similar powers to seek compensation. ${ }^{109}$

The explanatory memorandum to the Corporate Law Reform Bill acknowledged the possibility that the court could order punitive damages, which clearly recognises the dual role that compensation plays in redressing the wrong suffered by the victim while simultaneously punishing the wrongdoer. ${ }^{110}$ Indeed, the Corporate Law Reform Act 1992 (Cth) inserted s 1317HB into the predecessor of the Corporations Act. This section allowed a criminal court to order compensation where 'a court finds a person guilty of an offence constituted by a contravention of a civil penalty provision in relation to a corporation'. While this section has subsequently been repealed, ${ }^{111} \mathrm{~s} 588 \mathrm{~K}$ of the Corporations Act

104 Ibid 6

105 Explanatory Memorandum, Corporate Law Reform Bill 1992 (Cth) 31 [120].

106 Senate Standing Committee on Legal and Constitutional Affairs, Parliament of Australia, Company Directors' Duties (1989) ('Cooney Report').

107 Ibid 190

108 Ibid 80.

109 For example, the Australian Competition and Consumer Commission can seek compensation orders for victims of cartel behaviour under Competition and Consumer Act 2010 (Cth) ss 87(1A)(b), 87(1B). The Fair Work Ombudsman can seek compensation orders under s 545(2)(b) of the Fair Work Act 2009 (Cth). Similar powers are held by regulators in other jurisdictions. For example, the Financial Services Authority in the UK is able to apply for compensation orders and investigate and seize assets. Financial Services and Markets Act 2000 UK ss 382 and 383.

110 Explanatory Memorandum, Corporate Law Reform Bill 1992, [179].

111 Ibid [181]. This provision was removed by the Corporate Law Economic Reform Program Act 1999 (Cth). Under s 1317HB, the criminal court could make a civil penalty order. The 1999 amendments required ASIC to commence fresh proceedings to obtain a civil penalty order if the criminal prosecution failed: Explanatory Memorandum to Corporate Law Economic Reform Program Bill, [6.128]. 
allows a criminal court to order compensation for insolvent trading. Insolvent trading, it should be recalled, includes uncommercial transactions where assets are transferred for undervalue. A criminal action can only be brought at the behest of the regulator.

However, to date ASIC has not used its power to seek a compensation order in the phoenix context. While ASIC has published data about enforcement since July 2011, ${ }^{112}$ it does not report which enforcement actions relate to phoenix activity. Therefore, other means had to be found to determine the level of its enforcement. This included searching a number of publicly available sources. ${ }^{113}$ The search began by looking at the Austlii case database and the ASIC's media releases from 1 January 2004 to 31 December 2014. These searches revealed that during this period ASIC issued civil penalty applications alleging a breach of duty on 19 separate occasions. ${ }^{114}$ In only one of those applications did the facts giving rise to the alleged breach of duty amount to illegal phoenix activity. This civil penalty application sought declarations of contravention, restraining orders and disqualification orders. ${ }^{115}$ Compensation was not sought by the regulator, and there is no explanation in the ASIC media release or the case report itself as to why ASIC only sought declarations and injunctions against the parties involved. ${ }^{116}$ This is despite the fact that the case has numerous references to unsatisfied statutory demands issued by the ATO and a workers' compensation insurer. ${ }^{117}$

In addition, ASIC's media releases and an accompanying search of the Austlii database did not reveal any ASIC applications commenced between 2004 and 2014 alleging directors had engaged in insolvent trading in breach of Corporations Act $\mathrm{s}$ 588G(2) in circumstances that may have involved illegal phoenix activity. It should be noted here that ASIC is not the only party that can bring action under s 588G, as liquidators may do so either in relation to insolvent trading itself 118 or for 'deemed' insolvent trading where the directors have entered into an uncommercial transaction within the meaning of s 588FB. ${ }^{119}$ The latter typically describes the circumstances of an undervalued asset transfer during phoenix activity. However, it is highly unlikely that the liquidator will bring action of this nature because phoenixed companies typically

112 See http://asic.gov.au/about-asic/asic-investigations-and-enforcement/asic-enforcementoutcomes/.

113 For the details of sources searched and the methodology in collating information, as well as the results of our empirical research into phoenix enforcement by ASIC and other regulators, see Helen Anderson et al, Quantifying Phoenix Activity: Incidence, Cost, Enforcement, Centre for Corporate Law and Securities Regulation, October 2015, pts 1.3 and 4.

114 ASIC, Media Releases (1 January 2004 - 31 December 2014) <http://asic.gov.au/aboutasic/media-centre/find-a-media-release/ $>$.

115 ASIC, 'Legal Adviser and Company Directors Found Liable in Relation to "Phoenix" Activity' (Media Release, 09-174AD, 14 September 2009) <http://asic.gov.au/aboutasic/media-centre/ find-a-media-release/2009-releases/09-174ad-legal-adviser-andcompany-directors-found-liable-in-relation-to-phoenix-activity/ $>$. The case itself is Australian Securities and Investments Commission v Somerville [2009] NSWSC 934; ASIC v Somerville (No 2) [2009] NSWSC 998; [2009] NSWSC 1149.

116 Australian Securities and Investments Commission v Somerville [2009] NSWSC 934, [2].

117 Australian Securities and Investments Commission v Somerville [2009] NSWSC 934.

118 Ie, where the requirements of s 588G(1) are satisfied.

119 For an explanation of this provision, see David Morrison, 'The Addition of Uncommercial Transactions to s 588G and its Implications for Phoenix Activities' (2002) 10 Insolvency Law Journal 229. 
have few or no assets to fund recovery litigation. ${ }^{120}$ Even if the liquidator does bring the action, it would only benefit the individual creditors of a specific company and may be unheard of beyond those circles. If ASIC brings the action, the public benefit of deterrence can also be achieved through the publicising of the case.

ASIC does disqualify directors involved in phoenix activity but even those instances are relatively few. ${ }^{121}$ Our searches revealed that between 1 January 2004 and 30 June 2014, ASIC disqualified 51 directors in circumstances involving phoenix activity. ${ }^{122}$ However, where ASIC does disqualify a director, it is often in circumstances where wrongful behaviour in addition to the phoenixing has occurred. For example, an ASIC media release recently recounted the disqualification of a Sydney director by ASIC. ${ }^{123}$ It stated that ' $[\mathrm{t}]$ he disqualification follows an ASIC investigation which found that $\mathrm{Mr}$ Teys breached his duties as a director, including failing to comply with financial services laws.' ${ }^{124} \mathrm{He}$ had been the director of three liquidated companies, one of which operated as an incorporated legal practice. It stated that Mr Teys had managed the companies 'such that each incurred a deficiency', that the incorporated legal practice had 'preferred trade creditors over the ATO and in so doing acted with a lack of commercial morality', that Mr Teys had '[u]sed his position as a director of Teys Lawyers and TPL improperly to gain financial advantages for himself and other related parties' and that several breaches of the duty of care had also occurred. ${ }^{125}$ The three company's deficiencies to creditors were in excess of $\$ 5$ million. 126

The media release quoted ASIC Commissioner Greg Tanzer as saying '[d]irectors have a responsibility to manage the financial affairs of their company in accordance with the law. As this case shows, directors who cause or permit their company to breach legal obligations can face significant consequences.' Mr Teys has been banned from managing

120 An exception is HWY Rent Pty Ltd $v$ HWY Rentals (in liq) (No 2) [2014] FCA 449. It is also possible that the uncommercial transaction provision has been used by liquidators to threaten directors, and that the directors have contributed extra funds to the liquidation to forestall a recovery action. In some cases, funding for recovery litigation may be provided by the ATO when it is a major creditor.

121 Further instances of enforcement by ASIC, other regulators and liquidators are recounted in Anderson et al, Defining and Profiling phoenix activity, above n 22. See also Anne Matthew, 'The Conundrum of Phoenix Activity: Is Further Reform Necessary?' (2015) 23 Insolvency Law Journal 116, which details the heavy emphasis placed by ASIC on administrative disqualification.

122 Anderson et al, Quantifying Phoenix Activity, above n 113, [4.2.1.4].

123 Corporations Act 2001 (Cth) s 206F. Note that disqualification by the court can also be sought by ASIC pursuant to s 206D.

124 ASIC, 'ASIC Disqualifies Sydney Director' (Media Release, 16-037MR, 18 February 2016) $<$ http://asic.gov.au/about-asic/media-centre/find-a-media-release/2016-releases/16037mr-asic-disqualifies-sydney-director/>.

125 Ibid.

126 In a similar vein, see Australian Securities and Investments Commission, 'ASIC Disqualifies Melbourne Director' (Media Release, 15-037MR, 7 December 2015) <http://asic.gov.au/about-asic/media-centre/find-a-media-release/2015-releases/15370mr-asic-disqualifies-melbourne-director/> regarding John Paulding, whose insolvent companies lost over $\$ 3.5$ million. ASIC's media release noted that he '[f]ailed to exercise his duty to act in good faith in the best interest of Paulding Constructions or for a proper purpose' and he '[c]oncealed and removed assets of Paulding Constructions so that they were not readily realisable by the current liquidators.' 
corporations for five years, the maximum amount allowable under ASIC's administrative disqualification power.

The lack of applications for compensation by ASIC in the case of phoenix activity echoes ASIC's other civil penalty applications alleging breaches of duty that do not involve phoenix activity. A 2014 study into ASIC's use of the civil penalty regime revealed that the regulator has issued a total of 38 civil penalty applications alleging a breach of the directors' duties between 1993, when this enforcement regime was introduced, and 2014. ${ }^{127}$ In only 11 of those cases did the regulator seek a compensation order, and it has never been the sole order sought. ${ }^{128}$ Disqualification orders were sought in 32 cases and pecuniary penalties were sought in 26 cases. ${ }^{129}$ Seeking compensation is clearly not ASIC's priority when it issues these applications, and this appears to be increasingly the case with the last compensation order being sought in $2006 .{ }^{130}$ So while ASIC's powers to seek compensation of behalf of creditors could theoretically assist them, in reality this has not occurred.

One can only speculate as to why ASIC has chosen this path. This might be because seeking compensation could delay the resolution of public enforcement actions and place additional financial burdens on the regulator. ${ }^{131}$ It is certainly understandable that ASIC may be reluctant to raise expectations in that regard. It may also be concerned not to be seen as the hero for some creditors but not for others. However, ASIC already undeniably disappoints creditors in terms of any of the actions it brings. The 2014-2015 external administrator statistics compiled by ASIC showed 16,279 reports of suspected civil misconduct. ${ }^{132}$ Enforcement statistics for the second six months of that period show that across all of ASIC's operations, it '(a) commenced 136 investigations; (b) completed 137 investigations; (c) charged 10 individuals with a total of 82 criminal charges; (d) banned 25 individuals from the financial services or credit industries; (e) accepted six enforceable undertakings; and (f) disqualified 19 directors.' ${ }^{133}$ A recent Productivity Commission report commented that 'rather than crafting new offences, improvements in the detection and enforcement of existing laws are likely to be the best option for creating a genuine disincentive for directors contemplating phoenix action.' 134

Perhaps it is simply a matter of ASIC's enforcement priorities being elsewhere. ${ }^{135} \mathrm{In}$ relation to their 'Priority 1: Investor and financial consumer trust and confidence', 136 ASIC obtained '\$36.1 million in total compensation or remediation ... for investors and financial consumers' ${ }^{\prime 37}$ and raised $\$ 18,975,000$ in penalties through civil penalty

127 Welsh, above n 6, 233.

128 Ibid 237-38.

129 Ibid.

130 This ultimately unsuccessful application was issued against Fortescue Metals Group and Andrew Forrest: Forrest v Australian Securities and Investments Commission (2012) 247 CLR 486.

131 Hodges, above n 87, 216.

132 ASIC, 'Insolvency Statistics: External Administrators' Reports (July 2014 to June 2015)' (Report, REP 456, November 2015) table 10, 19.

133 ASIC, 'ASIC Enforcement Outcomes: January to June 2015' (Report, REP 444, August 2015) 4 [4].

134 Productivity Commission, Business Set-up, Transfer and Closure Productivity Commission Inquiry Report, Report No 75 (September 2015) 425.

135 See further SERC, Performance of ASIC, above $\mathrm{n} 8$, chapter 17

136 ASIC, Annual Report 2014-2015 (October 2015) 6.

137 Ibid 164. 
action. ${ }^{138}$ In contrast, in relation to 'Priority 2: Fair, orderly, transparent and efficient markets', ${ }^{139}$ which covers the insolvency area amongst other things, ASIC did not obtain any pecuniary penalties and only $\$ 943,418$ as '[c]ompensation or remediation secured for investors and financial consumers'. ${ }^{140}$ Our searches indicate that none of this compensation relates to actions in relation to illegal phoenix activity.

It is also possible that ASIC's lack of response to misconduct in the insolvency context is symptomatic of wider problems. ASIC was criticised extensively in the Senate Economics References Committee report considering ASIC's performance in 2014. The committee commented that 'ASIC has limited powers and resources but even so appears to miss or ignore clear and persistent early warning signs of corporate wrongdoing' ${ }^{\prime}{ }^{141}$ The committee's report outlined 10 pages of complaints about ASIC's response to complaints and reports of misconduct, ${ }^{142}$ following which the committee stated that it had 'received many other complaints that are too numerous to detail here about ASIC's supposedly inadequate response. ${ }^{143}$ The committee recommended a system by which external administrators could indicate to ASIC which reports required 'the most urgent attention and investigation' 144 but the recommendation was simply 'noted' by the government. It stated that ASIC 'has worked, and continues to work' on its own systems to identify statutory reports requiring urgent attention. ${ }^{145}$

One relevant area of enforcement that ASIC has pursued involves the conduct of liquidators themselves. ${ }^{146}$ Part III above noted that creditors' recovery could be adversely affected by advisors who are themselves accessories to the phoenix activity of their clients. ASIC maintains that liquidators are the gatekeepers here ${ }^{147}$ and should bring actions against directors for breaches of duty and for recovery of payments improperly made prior to liquidation. ASIC's response ${ }^{148}$ is undoubtedly a result of the

138 Ibid 7

139 Ibid 8.

140 Ibid 9 .

141 Senate Economic References Committee, Performance of ASIC, above n 8, xvii.

142 Ibid 227-236.

143 Ibid [15.38].

144 Ibid [15.66].

145 Australian Government, Australian Government Response to the Senate Economic References Committee Report, 'Performance of the Australian Securities and Investments Commission (2014) 9.

146 For example, Andrew Dunner (ASIC v Dunner [2013] FCA 872); Pino Fiorentino, removed by CALDB, (see ASIC, 'ASIC Removes Liquidator from Industry' (Media Release, 14-160MR, 8 July 2014) <http://asic.gov.au/about-asic/media-centre/find-a-media-release/2014releases/14-160mr-asic-removes-liquidator-from-industry/>); and Stuart Ariff, jailed for six years, (see ASIC, 'Stuart Ariff Jailed on ASIC Charges' (Media Release, 1-308MR, 19 December 2011) <http://asic.gov.au/about-asic/media-centre/find-a-media-release/2011releases/11-308mr-stuart-ariff-jailed-on-asic-charges/>) whose actions (and ASIC's response to them) prompted the Senate Economics References Committee's report into the regulation, registration and remuneration of insolvency practitioners in Australia (Senate Economics References Committee, Parliament of Australia, The Regulation, Registration and Remuneration of Insolvency Practitioners in Australia: The Case for a New Framework (2010)).

147 See discussion in Matthew, above n 121, 131-2. See also Greg Tanzer, 'Rise of the Phoenix: ASIC Campaign Focuses on Gatekeepers' (2014) Law Society Journal 34, 34.

148 ASIC, Corporate Plan 2015-16 to 2018-19 (August 2015) 16-17. 'Insolvency practitioners review high-risk insolvency practitioners focussing on independence (including pre insolvency advisers), competence and improper gain (including remuneration) ... 
2010 Senate inquiry into insolvency practitioners. ${ }^{149}$ Since 2012 , ASIC has released an annual report into the regulation of registered liquidators. ${ }^{150}$ This summarises the complaints made against liquidators and the action that ASIC took in response. It is noteworthy that there is no equivalent document that tallies complaints about company officers, made through external administrators' statutory reports, with actions taken against those officers. The only enforcement reporting that ASIC provides is of a general nature that does not allow matching of complaints against enforcement. ${ }^{151}$ In addition, since 2013, ASIC has undertaken a project to test all registered liquidators' compliance with requirements to publish notices and lodge documents, and the results are then published. ${ }^{152}$

\section{CONCLUSION}

The victims of illegal phoenix activity include the ATO, state revenue authorities, employees, trade creditors and competitors. There are a number of difficulties faced by these victims in seeking redress for their losses. Those difficulties arise as a result of many factors that include the limited liability that is enjoyed by companies and exploited in the phoenix context, the rules regulating the distribution of funds in insolvency, the limitations faced by liquidators, the absence of a specific phoenix offence and a lack of standing to enforce breaches of the directors' duties that may occur in the insolvency context. While some differences between creditors arise, the grievance that is suffered by most unsecured creditors is the non-payment of debts in full by an insolvent company from which assets have been stripped at undervalue. One way of improving their position in this context is to increase the pool of funds available for distribution to unsecured creditors by seeking compensation from directors personally.

Both the liquidator and ASIC can issue proceedings seeking compensation against directors that have phoenixed their companies. However, practical difficulties faced by liquidators mean that these types of actions are issued infrequently. Assisting creditors by seeking compensation orders against directors who have phoenixed their companies can be an appropriate use of ASIC's resources, especially where doing so does not detract from its traditional enforcement role. We acknowledge that the issue of ASIC's reluctance to seek compensation is not unique to the insolvency or phoenix situation, but the need for the regulator to act is particularly acute in the phoenix context because of the limited rights that creditors have to act on their own behalf. However, the data

Lodgement compliance - review systemic non-compliance by insolvency practitioners with statutory lodgement obligations ... Identify inappropriate conduct by assessing reports of misconduct and deciding whether we need to act further - we expect gatekeepers to report issues promptly so we can rectify problems with individual entities quickly and effectively.'

149 Senate Economics References Committee, The Regulation, Registration and Remuneration of Insolvency Practitioners, above n 146.

150 ASIC, 'ASIC Regulation of Registered Liquidators: January to December 2011' (Report, REP 287, 22 May 2012). ASIC, 'ASIC Regulation of Registered Liquidators: January to December 2012' (Report, REP 342, 1 May 2013); ASIC, 'ASIC Regulation of Registered Liquidators: January to December 2013' (Report, REP 389, 8 April 2014); ASIC, 'ASIC Regulation of Registered Liquidators: January to December 2014' (Report, REP 430, 16 April 2015).

151 ASIC, 'ASIC Enforcement Outcomes: January to June 2015' (Report, REP 444, August 2015).

152 See for example, ASIC, 'ASIC Cancels Registration of Liquidators' (Media Release, 15-224MR, 24 August 2015) <http://asic.gov.au/about-asic/media-centre/find-a-media-release/2015releases/15-224mr-asic-cancels-registration-of-liquidators/ 24 August 2015>. 
suggests that currently these types of proceedings do not provide assistance to creditors because ASIC does not see the obtaining of compensation orders as a genuine objective.

It is to be hoped that in future, ASIC considers the issues raised here when it contemplates actions against directors engaged in illegal phoenix activity. At the very least, the Corporations Act could be altered to have a provision like the Fair Work Act where a court imposing a penalty can order it be paid to the employees. ${ }^{153}$ Under the Corporations Act, it would be payable to the liquidator. However, given the criticisms of ASIC in the SERC Performance of ASIC Report in 2014, as well as those noted by the SERC examination of insolvency practitioners in $2010,{ }^{154}$ one wonders whether the time has come for a dedicated regulator to deal with insolvency, ${ }^{155}$ like the Insolvency Service in the United Kingdom.

153 Fair Work Act 2009 (Cth) s 545(3), discussed above n 35.

154 Senate Economics References Committee, The Regulation, Registration and Remuneration of Insolvency Practitioners, above $\mathrm{n}$ 146, Chapter 6.

155 The first recommendation of the SERC in its 2010 report was that 'the corporate insolvency arm of ASIC be transferred to ITSA to form the Australian Insolvency Practitioners Authority (AIPA).' Ibid [11.9]-[11.10]. 